\title{
PENGARUH KECERDASAN SPIRITUAL DAN KONSEP DIRI TERHADAP PERSEPSI PERILAKU SEKS PRANIKAH SISWA KELAS X SMAN 1 DAGANGAN KABUPATEN MADIUN
}

\author{
Juwita Nurmahayati *) \\ H. Ibnu Mahmudi **)
}

\begin{abstract}
ABSTRAK
Penelitian ini bertujuan untuk mengetahui adanya pengaruh kecerdasan spiritual dan konsep diri terhadap persepsi perilaku seks pranikah siswa kelas X di SMAN 1 Dagangan Kabupaten Madiun.

Metode dalam penelitian adalah expost-facto, yaitu dengan cara mengungkap data tentang kecerdasan spiritual, konsep diri dan persepsi perilaku seks pranikah. Penetapan sampel penelitian menggunakan teknik random sampling dari populasi 180 siswa di ambil15\% yaitu 30 siswa, pengumpulan data menggunakan metode angket yaitu angket langsung dan tertutup. Penyebaran angket pada bulan September 2013. Analisis data penelitian menggunakan teknik analisis Regresi : Dua Prediktor.

Hasil penelitian dapat disimpulkan (1) Ada Pengaruh Kecerdasan Spiritual terhadap Persepsi Perilaku Seks Pranikah siswa kelas X SMAN 1 Dagangan Kabupaten Madiun, (2) Ada Pengaruh Konsep Diri terhadap Persepsi Perilaku Seks Pranikah siswa kelas X SMAN 1 Dagangan Kabupaten Madiun, (3) Ada Pengaruh Kecerdasan Spiritual dan Konsep Diri terhadap Persepsi Perilaku Seks Pranikah siswa kelas X SMAN 1 Dagangan Kabupaten Madiun.

Saran dari penelitian ini adalah hendaknya siswa senantiasa meningkatkan kecerdasan spiritualnya dan dapat mengenal diri secara positif sehingga siswa memiliki persepsi yang negatif terhadap perilaku seks pranikah.
\end{abstract}

Kata Kunci: Kecerdasan Spiritual, Konsep Diri Persepsi Perilaku Seks Pranikah

* Juwita Nurmahayati adalah Mahasiswa Program Studi Bimbingan dan Konseling Fakultas Ilmu Pendidikan IKIP PGRI Madiun.

** Ibnu Mahmudi adalah Dosen Program Studi Bimbingan dan Konseling Fakultas Ilmu Pendidikan IKIP PGRI Madiun. 


\section{A. PENDAhuluan}

Sarwono (2004 dalam Fitria Aida dkk, 2013: 203) menjelaskan perilaku seksual pada remaja dipengaruhi oleh banyak faktor antara lain perubahan hormonal, pergaulan bebas, kurangnya pemahaman siswa terhadap kematangan seksual dan kurangnya informasi tentang seks. Pandangan bahwa seks adalah tabu ataupun dengan alasan lain membuat remaja enggan berdiskusi tentang kesehatan reproduksinya dengan orang lain. Hal seperti ini akan membuat remaja lebih nyaman untuk mencari tahu lewat teman, internet, maupun sumber lain bertolak dari benar atau salah informasi yang didapat.

Informasi yang salah tentang seks dapat mengakibatkan pengetahuan dan persepsi seseorang mengenai seluk beluk seks itu sendiri menjadi salah. Pengetahuan yang setengah-setengah justru lebih berbahaya dibandingkan tidak tahu sama sekali, kendati dalam hal ini ketidak-tahuan bukan berarti tidak berbahaya (Selamiharja dan Yudana, 1997 dalam Martina Evlyn dan Elizadiaani Dewi , 2007: 49). Hal tersebut pada akhirnya akan berdampak yang merugikan remaja itu sendiri.

Remaja SMA bisa dikatakan memiliki rasa ingin tahu yang sangat besar. Keingin-tahuan yang besar ini malah kadang menjerumuskan pada jalan yang salah bila rasa ingin tahu yang besar itu tidak mendapat jawaban yang baik dari sumber yang terpercaya seperti sekolah, keluarga, dan petugas kesehatan sehingga pandangan remaja terhadap seks pun ada yang positif juga ada yang negatif. Dengan semakin matangnya organ-organ seksual, maka timbul juga dorongan untuk pemuasan seksual. Tidak menutup kemungkinan, apabila ada kesempatan para remaja melakukan berbagai macam perilaku seksual seperti berpegangan tangan, berpelukan, bercumbu, memegang atau meraba bagian sensitif, petting, bahkan melakukan hubungan seksual yang jelas-jelas beresiko dan dilarang oleh hukum dan agama.

Agama merupakan sistem yang mengatur tata keimanan (kepercayaan) kepada Tuhan yang Mahakuasa, tata peribadatan, dan tata kaidah yang bertalian dengan pergaulan manusia dan manusia serta lingkungannya 
(Kamus Besar Bahasa Indonesia, 2008: 18). Pada dasarnya agama berkaitan dengan kepercayaan, maka dengan agama seseorang akan merasa aman dalam hidup ini dan karena memiliki rasa aman, kita akan merasakan ketetapan hati dalam menghadapi sesuatu dan bisa terhindar dari perbuatan yang sangat ditentang oleh agama.

Pemahaman agama remaja saat ini yang masih belum maksimal, seperti lebih memilih melihat tayangan televisi kesukaannya daripada meluangkan waktu untuk sholat, akan semakin menjauhkan diri dari nilai-nilai ketuhanan. Padahal, apabila remaja memiliki nilai religius yaitu kecerdasan spiritual di dalam kehidupan sehari-hari, maka akan mampu menolak segala pengaruh yang tidak baik karena secara tidak langsung Allah SWT akan melindungi dari segala hal yang dapat merusak keimanan. Dengan kata lain, kecerdasan spiritual ternyata memegang peranan yang cukup penting sebagai tindakan preventif untuk meminimalisir perilaku seks pranikah.

Persepsi seksual pranikah pada remaja juga dipengaruhi oleh konsep diri siswa, yaitu cara pandang individu yang menyeluruh terhadap diri yang menyangkut fisik, intelektual, emosional, sosial, dan spiritual yang mempengaruhi individu tersebut dalam berhubungan dengan orang lain. Remaja SMA yang sedang dalam masa mencari tahu akan mudah terpengaruh untuk mencoba rokok, minuman keras, ikut tawuran antar pelajar, bahkan melakukan perilaku seks di luar nikah.

Gejolak emosi yang terjadi akibat perubahan-perubahan yang dialami remaja ini, apabila tidak dapat dikendalikan, kemungkinan akan menjadi batu penghalang dalam pembentukan kecerdasan emosionalnya, hal ini dapat terjadi karena remaja tidak mampu menerima segala perubahan yang terjadi dalam dirinya, sehingga menilai dirinya secara negatif dan tidak mampu menghargai dan menerima segala kekurangan dan kelebihan yang ada pada dirinya, dengan kata lain remaja tersebut memiliki konsep diri yang rendah (negatif). Hal ini harus disikapi bersama-sama dalam membimbing dan mengarahkan siswa menjadi lebih baik dalam tatanan pendidikan. 
Berdasarkan penelitian awal yang dilakukan peneliti melalui observasi dan wawancara dengan salah satu konselor di SMAN 1 Dagangan, ditemukan beberapa perilaku yang mengarah pada perilaku seks pranikah. Hal tersebut ditunjukkan dengan sikap para siswa diantaranya terdapat siswa yang berciuman didalam kelas, bermesraan didalam kelas, berpegangan tangan dengan lawan jenis, bahkan ditemukan kasus siswa yang hamil diluar nikah. Menurut salah satu guru BK di SMA tersebut proses bimbingan konseling memang sudah berjalan, akan tetapi intensitasnya masih dirasa kurang. Hal tersebut akan berdampak pada tingkat spiritual siswa yang lama kelamaan akan terkikis oleh keadaan saat ini yang semakin bebas.

Dengan adanya hal tersebut, muncul kekhawatiran dari konselor yang beranggapan apabila siswa tidak dibekali oleh dasar yang kuat tentang pendidikan seks baik dari sekolah melalui bimbingan dan konseling maupun dari luar sekolah misalnya dari kegiatan ormas yang menyelenggarakan pendidikan seksual remaja, akan berakibat munculnya perilaku seksual beresiko di kalangan siswa.

Mengingat saat ini pergaulan yang semakin bebas dan mengkhawatirkan, bahkan tidak lagi mengindahkan norma yang berlaku baik norma sosial maupun agama. Tindakan yang bisa dilakukan yaitu maraknya tawuran, mabuk-mabukan, tindakan kriminal, hubungan pertemanan antar lawan jenis yang semakin tidak sehat. Maka dari itu, bimbingan yang dilakukan oleh konselor juga dapat membentuk pola pikir siswa menuju ke arah dewasa.

Dari uraian di atas dapat disimpulkan bahwa kecedasan spiritual perlu dibangkitkan dalam proses pergaulan di masyarakat khususnya dengan lawan jenis untuk menghindari perbuatan yang dilarang oleh agama. Selain itu, penanaman terhadap pembentukan konsep diri siswa harus benar-benar diperhatikan sejak dini. Semaksimal mungkin siswa harus terhindar dari internalisasi konsep diri yang negatif agar siswa tersebut dapat terhindar dari perbuatan yang tercela yang bisa memicu ke arah asusila yaitu hubungan seks pranikah. Apabila siswa membentengi diri dengan kekuatan religius dan 
konsep diri yang baik, maka cara pandang siswa terhadap perilaku seks pranikah dapat berbeda-beda. Dengan berdasar pada asumsi tersebut, peneliti melakukan suatu penelitian yang berjudul "Pengaruh Kecerdasan Spiritual dan Konsep Diri terhadap Persepsi Perilaku Seks Pranikah Siswa Kelas X SMAN 1 Dagangan Kabupaten Madiun”.

\section{B. KAJIAN TEORI}

\section{Kecerdasan Spiritual}

Menurut Iskandar (2009: 65) kecerdasan spiritual merupakan kemampuan individu mengelola nilai-nilai, norma-norma, dan kualitas kehidupan dengan memanfaatkan kekuatan-kekuatan pikiran bawah sadar atau lebih dikenal dengan suara hati (God Spot).

Faisal Jalal (dalam Yudrik Jahja 2011: 406) juga menyatakan kecerdasan spiritual merupakan kecerdasan yang tidak hanya terkait dengan akan, atau penalaran, tetapi juga dengan jiwa dan hati atau roh.

Berdasarkan dua pendapat di atas, peneliti menyimpulkan bahwa kecerdasan spiritual merupakan kecakapan seseorang dalam dimensi rohaniah, kekuatan spiritrual, dan kekuatan jiwa yang dapat membantu membangun jiwa.

Tanda-tanda dari Spiritual Quotiont yang telah berkembang dengan baik menurut Roisatun Nisa' (2009: 26) mencakup hal-hal berikut: kemampuan bersikap fleksibel (adaptif secara spontan dan aktif), tingkat kesadaran yang tinggi, kemampuan untuk menghadapi dan memanfaatkan penderitaan, kemampuan untuk menghadapi dan melampaui rasa sakit, kualitas hidup yang diilhami oleh visi dan nilainilai, keengganan untuk menyebabkan kerugian yang tidak perlu, kecenderungan untuk melihat keterkaitan antara berbagai hal (berpandangan holistik), kecenderungan untuk bertanya "mengapa" atau "bagaimana jika" untuk mencari jawaban-jawaban yang mendasar.

Sedangkan menurut Zohar dan Marshall (dalam Budi Wahyu Satria, 2007: 4) kecerdasan spiritual mengandung beberapa aspek yang 
merupakan ciri dari kecerdasan spiritual yang tinggi, yaitu : 1) Sikap ramah-tamah, yaitu adanya minat bersosialisasi, menyesuaikan diri dengan kelompok, dan menikmati berbagai aktifitas kelompok, 2) Kedekatan yaitu kebutuhan untuk memberikan cinta atau merasa dicintai, 3) Keingintahuan, yaitu dorongan untuk menyelidik, tertarik dengan berbagai hal, 4) Kreativitas, yaitu membuat sesuatu yang belum pernah ada sebelumnya, 5) Konstruksi, yaitu memiliki perasaan batiniah yang kaya, menekankan pada kontrol diri, harga diri, 6) Penegasan diri yaitu berkaitan dengan pengabdian kepada masyarakat dan untuk kepentingan transpersonal, 7) Religius, yaitu berkaitan dengan penemuan makna dan nilai dalam segala aktifitas.

Dari kedua pendapat di atas, peneliti menyimpulkan bahwa individu yang mempunyai kecerdasan spiritual yaitu: beriman dan bertaqwa kepada Tuhan, mempunyai rasa kasih sayang antar sesama,, memiliki kesadaran (self awareness) yang tinggi, membuat keberadaan dirinya bermanfaat untuk orang lain, ucapan dan tindakannya selalu mencerminkan nilai-nilai luhur, moral dan etika agama.

\section{Konsep Diri}

John W. Santrock (2007: 183) mengemukakan konsep diri (self concept) adalah evaluasi yang menyangkut bidang-bidang tertentu dari diri.

Hendrianti Agustiani (2009: 43) juga berpendapat konsep diri merupakan gambaran yang dimiliki seseorang tentang dirinya, yang dibentuk melalui pengalaman-pengalaman yang diperoleh dari interaksi dengan lingkungan.

Bertolak dari beberapa pengertian ahli diatas, maka peneliti merumuskan bahwa konsep diri adalah sejauh mana seorang siswa memberikan gambaran terhadap diri, yang berkaitan dengan fisik maupun non fisik yang sangat berperan dalam aktifitas sehari-hari di sekolah.

Mujiono, $\operatorname{dkk}(2010$ : 15), bahwa konsep diri yang terdiri dari konsep diri positif dan negatif memiliki ciri-ciri sebagai berikut sebagai berikut: 
1) Individu yang memiliki konsep diri yang positif adalah: Dapat menerima dirinya secara apa adanya dengan segala resiko kekuatan dan kelemahannya, memiliki pengetahuan dan wawasan yang luas tentang dirinya, membuat harapan-harapan dan perencanaan yang masuk akal, serta kemungkinan besar dapat dicapai, tidak merasa terancam dan cemas jika dikritik dengan informasi negatif tentang dirinya; sebaliknya pribadi yang positif tidak hanyut ketika disanjung dengan informasi positif tentang dirinya.

2) Individu yang memiliki konsep diri negatif yaitu: Konsep diri negatif terjadi pada individu yang tidak banyak tahu tentang dirinya, tidak melihat dirinya secara utuh. Hanya melihat diri atau kelebihan, sehingga hanya membangun harapan-harapan diri yang tidak realistis.

Berdasarkan uraian di atas dapat disimpulkan bahwa terdapat karakteristik konsep diri positif antara lain: dapat menerima diri sendiri secara apa adanya, mampu menempatkan diri dalam lingkungan sekolah, dapat menyimpan informasi baik informasi negatif maupun informasi positif, dapat memahami dan menerima sejumlah fakta yang sangat bermacam-macam tentang diri sendiri, dapat mengenal diri dengan baik dan menerima orang lain

\section{Persepsi Perilaku Seks Pranikah}

\section{a) Persepsi}

Slameto (2010: 102) persepsi merupakan proses yang menyangkut masuknya pesan atau informasi ke dalam otak manusia. Sedangkan Chaplin (dalam Desmita, 2009: 117) berpendapat persepsi sebagai proses mengetahui atau mengenali objek dan kejadian objektif dengan bantuan indra.

Berdasarkan beberapa pendapat di atas, peneliti menyimpulkan yang dimaksud persepsi adalah masuknya informasi melalui alat indra manusia sekaligus memahami informasi tersebut untuk kepentingan tertentu. 


\section{b) Perilaku Seks Pranikah}

Menurut Sarlito W. Sarwono (2011: 174) perilaku seksual adalah segala tingkah laku yang didorong oleh hasrat seksual, baik dengan lawan jenisnya maupun dengan sesama jenis.

Stuart dan Sundeen (dalam Ririn Darmasih, 2009: 17) perilaku seksual yang sehat dan adaptif dilakukan ditempat pribadi dalam ikatan yang sah menurut hukum.

Berdasarkan pendapat di atas, dapat disimpulkan bahwa perilaku seks pranikah adalah segala tingkah laku yang didorong oleh keinginan seksual tanpa melalui proses pernikahan yang resmi menurut hukum dan agama.

Berdasarkan uraian di atas peneliti menyimpulkan bahwa persepsi perilaku seks pranikah adalah suatu cara pandang dalam menilai tingkah laku yang didorong oleh hasrat seksual yang dimulai dari rasa tertarik dengan lawan jenis sampai berhubungan intim yang dilakukan tanpa adanya ikatan pernikahan secara sah menurut agama maupun hukum.

Sarlito W. Sarwono (2011: 188-204) berpendapat bahwa faktorfaktor penyebab masalah seksualitas pada remaja, yaitu: meningkatnya libido seksual, penundaan usia perkawinan, tabu-larangan, kurangnya informasi tentang seks, pergaulan yang makin bebas

Sementara itu, menurut Santrock (dalam Agoes Dariyo, 2004: 89) menyebutkan bahwa hal-hal yang mendorong remaja melakukan hubungan seks, kehidupan iman yang rapuh, faktor kematangan biologis

Berdasarkan dua pendapat di atas dapat disimpulkan bahwa faktorfaktor yang mempengaruhi hubungan seks pranikah antara lain: meningkatnya libido seksual, penundaan usia perkawinan, tabularangan, kurangnya infomasi tentang seks, pergaulan yang semakin bebas, hubungan seks, kehidupan iman yang rapuh, dan faktor kematangan biologis. 
Irawati (dalam Syamsul Huda B. Musthofah dan Fuji Winarti, 2010: 36) mengemukakan bentuk-bentuk perilaku seks pranikah remaja adalah sebagai berikut:

1) Berpegangan tangan yaitu merupakan simbol dari keakraban, kekompakan, persahabatan, kasih sayang, dan lain sebagainya yang hal tersebut dapat dilakukan baik oleh suami istri, orang tua dengan anaknya, sesama teman, orang yang berpacaran, sesama perempuan, dan lain-lain

2) Berpelukan adalah memeluk erat dan bersentuhan. Ini adalah cara yang sangat unik untuk berkomunikasi dan berbagi perasaan yang sangat bahagia sampai yang sangat menyedihkan dengan orang lain karena tidak adanya kata-kata yang diucapkan. Perilaku ini akan membuat jantung berdegup lebih cepat dan menimbulkan rangsangan seksual pada individu.

3) Cium kering adalah ciuman lembut dengan bibir terkatup, ke bibir dan bagian tubuh pasangan. Perilaku seksual cium kering berupa sentuhan pipi dengan pipi atau pipi dengan bibir.

4) Cium basah adalah ciuman yang dilakukan dengan bibir terbuka basah dan memainkan lidah. Sasaran ciuman ini bisa di bibir, serta di bagian tubuh yang sensitif. Dampak dari cium basah dapat menimbulkan dorongan seksual hingga tidak terkendali.

5) Meraba bagian tubuh yang sensitif merupakan suatu kegiatan meraba bagian tubuh yang sensitif, seperti payudara, vagina dan penis.

6) Petting adalah melakukan hubungan seksual dengan atau tanpa pakaian tetapi tanpa melakukan penetrasi penis ke dalam vagina. Jadi, sebatas digesekkan saja ke alat kelamin perempuan.

7) Oral seksual yaitu pada laki-laki ketika menggunakan mulut, bibir dan lidah pada penis dan sekitarnya. Sedangkan pada wanita, melibatkan bagian disekitar vulva yaitu labia, klitoris, dan bagian dalam vagina. 
8) Intercourse (berhubungan intim) merupakan aktivitas seksual dengan memasukkan alat kelamin laki-laki ke dalam alat kelamin perempuan, dampak dari perilaku seksual pranikah adalah perasaan bersalah, berdosa terutama pada saat pertama kali, ketagihan, kehamilan sehingga terpaksa menikah dan aborsi, kematian dan kemandulan akibat aborsi, resiko terkena penyakit seksual menular (PMS), sanksi sosial, agama serta norma, hilangnya keperawanan dan keperjakaan, merusak masa depan (terpaksa drop out dari sekolah).

Berdasarkan uraian diatas dapat disimpulkan beberapa bentuk perilaku seksual yang sering dijumpai pada remaja yaitu berpegangan tangan, berpelukan, berciuman, meraba bagian sensitif, petting, dan berhubungan intim.

\section{METODE PENELITIAN}

Penelitian ini menggunakan metode deskriptif expost facto yaitu penelitian yang digunakan untuk meneliti suatu peristiwa yang telah terjadi dan kemudian mengamati ke belakang tentang faktor-faktor yang dapat menyebabkan timbulnya kajian tersebut (Iskandar, 2009: 21-22). Sedangkan menurut Suharsimi Arikunto (2010: 17) metode expost facto merupakan suatu penelitian tentang variabel yang kejadiannya sudah terjadi sebelum penelitian dilaksanakan. Metode expost facto digunakan peneliti dengan pertimbangan karena data yang akan diungkap melalui metode ini sudah dimiliki oleh anggota sampel.

Penelitian dilaksanakan di SMAN 1 Dagangan yang beralamatkan di Desa Dagangan, Kecamatan Dagangan, Kabupaten Madiun, Jawa Timur. Waktu penelitian dilaksanakan pada bulan September 2013 sampai bulan Januari tahun 2014

Populasi dan sampel dalam penelitian ini adalah siswa kelas X SMA Negeri 1 Dagangan Kabupaten Madiun yang terdiri dari 6 kelas dengan 
jumlah siswa sebanyak 180 siswa, ditetapkan sekitar 15\% maka sebanyak 30 siswa secara acak.

Peneliti menggunakan angket tertutup dalam bentuk pilihan ganda dengan empat jawaban alternatif: a) Selalu b) Sering c) Kadang-kadang d) Tidak pernah. Jumlah item untuk masing-masing variabel sama, yaitu 20 pertanyaan.

Menurut Saifuddin Azwar (2010: 52) pemberian skor hasil isian angket berdasarkan distribusi skor yang favorabel dan unfavorabel. Secara rinci dapat dilihat pada tabel berikut.

Tabel Distribusi Skor Untuk Jawaban Angket Favorabel dan Unfavorabel

\begin{tabular}{|l|c|c|c|c|}
\hline \multicolumn{1}{|c|}{ Jawaban } & Selalu & Sering & Kadang & Tidak Pernah \\
\hline $\begin{array}{l}\text { Skor } \\
\text { Favorabel }\end{array}$ & 4 & 3 & 2 & 1 \\
\hline $\begin{array}{l}\text { Skor } \\
\text { Unfavorabel }\end{array}$ & 1 & 2 & 3 & 4 \\
\hline
\end{tabular}

Validitas angket dapat diuji dengan teknik validitas logis, yaitu validitas yang diukur dari kecocokannya sehingga secara logika dapat diterima. Data yang diperoleh kemudian di hitung menggunakan korelasi produk moment, dengan rumus:

$$
r_{x y}=\frac{N \sum X Y-\left(\sum X\right)\left(\sum Y\right)}{\sqrt{\left.\left\{N \sum X^{2}-\left(\sum X\right)^{2}\right\} N \sum Y^{2}-\left(\sum Y\right)^{2}\right\}}}
$$

(Suharsimi Arikunto, 2010: 171)

Keterangan:

$r_{x y} \quad=$ koefisien kolerasi product moment

$\sum x y=$ Jumlah perkalian skor item

$N \quad=$ jumlah responden

$\sum x \quad=$ nilai butir soal

$\sum y=$ nilai total 
Kriteria validitas menggunakan nilai $\mathrm{r}$ dari Product Moment dengan taraf signifikan 5\%. Jika nilai $\mathrm{r}$ hitung $\geq \mathrm{r}$ tabel maka item dinyatakan valid. Untuk uji validitas dalam penelitian ini penulis menggunakan rumus korelasi product moment. Instrument dikatakan valid jika butir soal mempunyai koefisien korelasi $r_{x y}>0,361$.

Sedangkan reliabilitas angket menggunakan rumus Spearman Brown yakni rumus reliabilitas Split half (Belah Dua). Dalam penelitian rumus reliabilitas Split half yang digunakan adalah dengan teknik ganjilgenap. Adapun rumus Spearman Brown Split half (belah dua) dengan teknik ganjil genap yaitu adalah sebagai berikut :

$$
r_{11}=\frac{2 x r_{1 / 21 / 2}}{1+r_{1 / 21 / 2}}
$$

(Suharsimi Arikunto,2010:223)

Keterangan :

$r_{11}=$ reliabilitas instrumen

$r_{1 / 21 / 2}=\boldsymbol{r}_{\boldsymbol{x y}}$ yang disebutkan sebagai indeks korelasi antara dua belahan.

Kriteria penyajian jika $r_{\text {hitung }}>r_{\text {tabel }}$ maka item dinyatakan reliabel.

Berdasarkan uji validitas semua item angket dinyatakan reliabel, maka angket yang dinyatakan valid dan reliabel dapat digunakan sebagai instrumen untuk mengungkapkan data tentang pengaruh kecerdasan spiritual dan konsep diri siswa terhadap persepsi perilaku seks pranikah.

Analisis Data Tentang Pengaruh Kecerdasan Spiritual dan Konsep Diri terhadap Persepsi Perilaku Seks Pranikah. Data ini dianalisis dengan menggunakan “Analisis Regresi Linier : Dua-Prediktor”, dengan rumus sebagai berikut : 


$$
R_{y(1,2)}=\sqrt{\frac{a_{1} \sum x_{1} y+a_{2} \sum x_{2} y}{\sum y^{2}}}
$$

(Suharsimi Arikunto, 2009: 387)

Keterangan :

$$
\begin{array}{ll}
\boldsymbol{R}_{y(1,2)} & : \text { Koefisien korelasi antara } \mathrm{Y} \text { dengan } \mathrm{X}_{1} \text { dan } \mathrm{X}_{2} \\
\boldsymbol{a}_{2} & : \text { Koefisien prediktor } \mathrm{X}_{2} \\
\boldsymbol{a}_{1} & : \text { Koefisien prediktor } \mathrm{X}_{1} \\
\sum x_{1} y & : \text { Jumlah produk antara } \mathrm{X}_{1} \text { dan } \mathrm{Y} \\
\sum x_{2} y & : \text { Jumlah produk antara } \mathrm{X}_{2} \text { dan } \mathrm{Y} \\
\sum y^{2} & : \text { Jumlah kuadrat kriterium } \mathrm{Y}
\end{array}
$$

Untuk menguji keberartian koefisien regresi secara keseluruhan digunakan uji $\mathrm{F}$ dengan rumus :

$$
F_{\text {reg }}=\frac{R^{2}(n-m-1)}{m(1-R)^{2}}
$$

(Suharsimi Arikunto, 2009: 453)

Keterangan:

$F_{\text {reg }}=$ Hasil $\mathrm{F}$ regresi

$n=$ Banyak anggota sampel

$m \quad=$ Banyak prediktor

$R=$ Koefisien korelasi antara kriterium dengan prediktor-prediktor.

\section{HASIL PENELITIAN}

\section{Deskripsi Data}

Hasil analisis deskriptif ini didasarkan pada perhitungan menggunakan Microsoft Exel 2010 dan secara manual. 
a. Deskripsi Data Kecerdasan Spiritual

Data kecerdasan spiritual diperoleh hasil hitung mean $=63$ median $=62$ modus $=72,78$, dan standart deviasi $=147,2$. Nilai tertinggi $=74$, nilai terendah 50 , rentang kelas 74,5 $-49,5=25$. Selanjutnya banyaknya kelas interval $=5$, maka dapat diperoleh panjang kelas $=5$.

b. Deskripsi Data Konsep Diri

Data untuk konsep diri diperoleh hasil hitung mean $=51$, median $=63,3$ modus $=68$, dan standart deviasi $=131,8$. Nilai tertinggi $=68,1$, nilai terendah 47 , dengan demikian rentang kelas $73,5-47,5=27$. Selanjutnya banyaknya kelas interval $=5$, maka dapat diperoleh panjang kelas $=5$.

c. Deskripsi Data Persepsi Perilaku Seks Pranikah

Data untuk persepsi perilaku seks pranikah diperoleh hasil hitung mean $=63,1$, median $=65,8$, modus $=71,2$, dan standart deviasi $=123$. Nilai tertinggi $=77$, nilai terendah 42 , dengan demikian rentang kelas $77-42=35$. Selanjutnya banyaknya kelas interval $=6$, maka dapat diperoleh panjang kelas $=5$.

\section{Hasil Analisis Data}

a. Hasil analisis pengaruh Kecerdasan Spiritual terhadap Persepsi Perilaku Seks Pranikah

Dari hasil perhitungan menunjukkan $r_{\text {hit }}=0,44$ sedangkan $\mathrm{r}_{\text {tabel }}$ dengan taraf signifikan $5 \%$ untuk $\mathrm{N}$ sebanyak 30 diperoleh nilai 0,361. Dari hasil tersebut berarti $r_{\text {hit }}(0,44)>r_{\text {tab }}(0,361)$ ini menunjukkan ada pengaruh antara kecerdasan spiritual terhadap persepsi perilaku seks pranikah.

Koefisien determinasi sebesar 0,15 memperlihatkan bahwa kecerdasan spiritual memberikan sumbangan sebesar $15 \%$ terhadap persepsi perilaku seks pranikah.

b. Hasil analisis pengaruh Konsep Diri terhadap Persepsi Perilaku Seks Pranikah 
Dari hasil perhitungan menunjukkan $r_{\text {hit }}=0.699$ sedangkan $\mathrm{r}_{\text {tabel }}$ dengan taraf signifikan $5 \%$ untuk $\mathrm{N}$ sebanyak 30 diperoleh nilai 0,361 . Dari hasil tersebut berarti $r_{\text {hit }}(0,699)>r_{\text {tab }}(0,361)$ ini menunjukkan ada pengaruh antara konsep diri terhadap persepsi perilaku seks pranikah.

Koefisien determinasi sebesar 0,60 memperlihatkan bahwa konsep diri memberikan sumbangan sebesar $60 \%$ terhadap persepsi perilaku seks pranikah.

c. Hasil analisis pengaruh Kecerdasan Spiritual dan Konsep Diri terhadap Persepsi Perilaku Seks Pranikah

Dari hasil perhitungan $F_{\text {hitung }}=41,99$ sedangkan $F_{\text {tabel }}$ dengan taraf signifikan 5\% untuk $\mathrm{N}$ sebanyak 30 diperoleh nilai 3,26. Dari hasil tersebut berarti $F_{\text {hitung }}(41,99) \geq F_{\text {tabel }}(3,26)$ ini menunjukan ada pengaruh antara kecerdasan spiritual dan konsep diri terhadap persepsi perilaku seks pranikah

Koefisien determinasi sebesar 0,75 memperlihatkan bahwa kecerdasan spiritual dan konsep diri memberikan sumbangan sebesar $75 \%$ terhadap persepsi perilaku seks pranikah.

\section{Simpulan Hasil Pengujian Hipotesis}

Berdasarkan hipotesis penelitian, maka dalam penelitian ini dikemukakan simpulan pengujian hipotesis sebagai berikut:

1. Ada pengaruh kecerdasan spiritual terhadap persepsi perilaku seks pranikah siswa kelas X SMAN 1 Dagangan Kabupaten Madiun, diterima.

2. Ada pengaruh konsep diri terhadap persepsi perilaku seks pranikah siswa kelas X SMAN 1 Dagangan Kabupaten Madiun, diterima.

3. Ada pengaruh kecerdasan spiritual dan konsep diri terhadap persepsi perilaku seks pranikah siswa kelas X SMAN 1 Dagangan Kabupaten Madiun, diterima. 


\section{E. PENUTUP}

\section{Simpulan}

Berdasarkan analisis data dari penelitian yang telah dilaksanakan diperoleh beberapa simpulan sebagai berikut:

a. Ada pengaruh kecerdasan spiritual terhadap persepsi perilaku seks pranikah siswa kelas X SMAN 1 Dagangan Kabupaten Madiun.

b. Ada pengaruh konsep diri terhadap persepsi perilaku seks pranikah siswa kelas X SMAN 1 Dagangan Kabupaten Madiun.

c. Ada pengaruh kecerdasan spiritual dan konsep diri terhadap persespi perilaku seks pranikah siswa kelas X SMAN 1 Dagangan Kabupaten Madiun.

\section{Saran}

Orang tua hendaknya memantau perkembangan anak. Selain itu, orang tua hendaknya memberikan pemahaman dan arahan mengenai hal-hal yang berhubungan dengan perilaku seks secara terbuka kepada anak sehingga anak memiliki pemahaman yang baik tentang perilaku seks dan dapat menghindari perilaku seks pranikah.

Selain itu sebagai masukan bagi konselor, agar secara terbuka dan empati dalam pemberian bimbingan kepada siswa sehingga siswa merasa nyaman dan mampu mengungkapkan permasalahannya sehinggga kebutuhan psikologis siswa terpenuhi secara optimal. Hal ini sangat mendukung peningkatan kecerdasan spiritual dan konsep diri siswa.

\section{DAFTAR PUSTAKA}

Abdul Rahman Shaleh. 2009. Psikologi: Suatu Pengantar dalam Perspektif Islam. Jakarta: Kencana Prenada Media Group.

Aida Fitria, dkk. 2013. Persepsi Siswa tentang Perilaku Seksual Remaja dan Implikasinya terhadap Pelayanan Bimbingan dan Konseling. Konselor Jurnal Ilmiah Konseling Vol. 1 No. 1 (http//ejournal.unp.ac.id/index.php./konselor/, di unduh 13 agustus 2013).

Agoes Dariyo. 2004. Psikologi Perkembangan Remaja. Bogor: Ghalia Indonesia Ary Ginanjar Agustian. 2005. Rahasia Sukses Membangun Kecerdasan Emosi dan Spiritual. Jakarta: Arga. 
Budi Wahyu Satria. 2007.Kecerdasan Spiritual pada Perwira Tinggi TNI yang akan Menghadapi Pensiun.

(httpgunadarma.ac.idlibraryarticlesgraduatepsychology2007Artikel_105 02039, diunduh 5 september 2013).

Deddy Mulyana. 2007. Ilmu Komunikasi: Suatu Pengantar. Bandung: Remaja Rosda Karya.

Departemen Pendidikan Nasional. 2008. Kamus Besar Bahasa Indonesia Pusat Bahasa Edisi Keempat. Jakarta: Gramedia.

Desmita. 2009. Psikologi Pekembangan Peserta Didik: Panduan bagi Orang Tua dan Guru dalam Memahami Psikologi Ana Usia SD, SMP, dan SMA. Bandung: PT Remaja Rosda Karya.

Hendrianti Agustiani. 2009. Psikologi Perkembangan: Pendekatan Ekologi Kaitannya dengan Konsep Diri. Bandung: Refika Aditama.

Inge Hutagalung. 2007. Pengembangan Kepribadian: Tinjauan Praktis Menuju Pribadi Positif. Jakarta: Indeks.

Iskandar. 2009. Psikologi Pendidikan: Sebuah Orientasi Baru. Ciputat: Gaung Persada Press.

Martina Evlyn dan Elizadiaani Dewi. 2007. Hubungan Antara Persepsi tentang Seks dan Perilaku Seksual Remaja di SMA Negeri 3 Medan . Jurnal $\begin{array}{lllll}\text { Keperawatan } & \text { Rufaidah } & \text { Vol }\end{array}$ (http://rudiniagara.students.umm.ac.id/2011/03/03/26/bimbingan-konseling/, di unduh 13 Agustus 2013).

Mujiono, dkk. 2010. Modul Pengembangan Diri Melalui Layanan Bimbingan dan Konseling. Yogyakarta: Paramitra Publishing.

Ririn Darmasih. 2009. Faktor yang Mempengaruhi Perilaku Seks Pranikah Pada Remaja SMA di Surakarta. Skripsi tidak diterbitkan. Surakarta: Program Studi Kesehatam Masyarakat Universitas Muhmmadiyah Surakarta, (httpgunadarma.ac.idlibraryarticlesgraduatepsychology2007Artikel_105 02039, diunduh 5 september 2013).

Roisatun Nisa'. 2009. Aspek Kecerdasan Spiritual dalam Perspektif Al-Qur'an. Skripsi Tidak Diterbitkan. Program Pendidikan Agama Islam: UIN Malang, (http//ejournal.unp.ac.id/index.php./konselor/, di unduh 13 agustus 2013).

Saifuddin Azwar. 2010. Penyusunan Skala Psikologi. Yogyakarta: Pustaka Pelajar.

Santrock J.W. 2007. Remaja Edisi 11. Terjemahan oleh Benedictine Widyasinta. Surabaya: Airlangga.

Sarlito W. Sarwono. 2011. Psikologi Remaja. Jakarta: Rajagrafindo Persada.

Siti NurFatimah. 2012. Dinamika Konsep Diri Pada Orang Dewasa Korban Child Abused. EmphatyVol 1, No. 1, (http//ejournal.unp.ac.id/index.php./konselor/, diunduh 13 Agustus 2013).

Slameto. Belajar dan Faktor-faktor yang Mempengaruhi. 2010. Jakarta: Rineka Cipta.

Syamsul Huda B. Musthofah dan Fuji Winarti. 2010. Faktor yang mempengaruhi Perilaku Seks Pranikah Mahasiswa di Pekalongan Tahun 2009-2010. Jurnal Kesehatan Reproduksi Vol 1, No.1, (http//ejournal.unp.ac.id/index.php./konselor/, di unduh 13 agustus 2013). 
Suharsimi Arikunto. 2002. Prosedur Penelitian: Suatu Pendekatan Praktik Edisi Revisi V. Jakarta: Rineka Cipta.

2010. Manajemen Penelitian. Jakarta : Rineka Cipta.

2010. Prosedur Penelitian: Suatu Pendekatan Praktik Edisi Revisi 2010 . Jakarta: Rineka Cipta.

Sugiyono. 2013. Metode Penelitian Pendidikan: Pendekatan Kuantitatif, Kualitatif, dan $R$ \& D. Bandung: Alfabeta.

Yudrik Jahja. 2011. Psikologi Perkembangan. Jakarta: Kencana Prenada Media Group. 